\title{
Pengaruh Kemampuan Koneksi Matematika Terhadap Hasil Belajar Materi Garis Singgung Lingkaran SMPN 2 Sumbergempol Tulungagung
}

\author{
Miftahul Azizah" ${ }^{1)}$, Fitria Fauziyah ${ }^{2)}$ \\ ${ }^{122)}$ Tadris Matematika, Fakultas Keguruan dan Ilmu Pendidikan, Institut Agama Islam Negeri Tulungagung, \\ Jl. Mayor Sujadi Timur No. 46 Tulungagung, Tulungagung, Indonesia \\ email: ${ }^{1)}$ Miftahalazizah@gmail.com, ${ }^{2}$ Fitriafauziyah@gmail.com \\ (Received 30-05-2018, Reviewed 31-10-2018, Accepted 23-01-2019)
}

\begin{abstract}
The purpose of the research used to know whether there are influences between ability of mathematics connection with student learning result and also to know how huge the impact of that caused by both of variables. The research used quantitative approach, using pearson product moment correlation test as a test of the relationship between mathematical connection ability with student learning outcomes, before it used to has done normality test using kolmogorov-smirnov. First, took an instrument data first in the validity and reliability test. All of calculations start from valid and reliable tests to data analysis using 5\% significance level was used SPSS v-16 software. The hypothesis test resulted in a significance of 0.001 less than 0.05 it means there are correlation between mathematical connection ability and student learning outcomes. The correlation value pearson product's moment is 0.706 it means the relationships have strong category.
\end{abstract}

Keywords : Mathematics Connection, Student Learning Result

\begin{abstract}
Abstrak
Penelitian ini memiliki tujuan untuk mengetahui pengaruh diantara kemampuan koneksi matematika dengan hasil belajar siswa dan juga untuk mengetahui seberapa besar pengaruh yang ditimbulkan oleh kedua variabel tersebut. Penelitian menggunakan pendekatan kuantitatif, dengan menggunkana uji korelasi pearson productmoment sebagai uji hubungan antara kemampuan koneksi matematika dengan hasil belajar siswa, namun sebelumnya telah dilakukan uji normalitas menggunakan kolmogorov-smirnov. Sebelum pengambilan data instrumen terlebih dahulu di uji validitas dan reliabilitasnya. Uji hipotesis menghasilkan signifikansi 0,001 yang kurang dari 0,05 yang artinya terdapat korelasi antara kemampuan koneksi matemtika dan hasil belajar siswa. Nilai korelasi pearson product momentnya adalah 0,706 yang berarti hubungannya dalam kategori kuat.
\end{abstract}

Kata kunci: Kemampuan Koneksi Matematika, Hasil Belajar 


\section{PENDAHULUAN}

Matematika merupakan mata pelajaran sekolah yang dirancang sesuai dengan kemampuan dan kebutuhan siswa agar dapat mengembangkan ketajaman penalaran, berfikir logis, analitis, sistematis, kritis, dan inovatif. Perkembangan teknologi modern tidak terlepas dari adanya bantuan dari ilmu matematika dan dengan matematika manusia akan lebih mudah dalam memahami dan menguasai masalah agama, sosial, ekonomi, dan alam. sehingga dengan belajar matematika akan melatih siswa untuk berfikir kritis pada setiap hal yang berkaitan dengan bidang studi lain, maupun dengan hal-hal yang dihadapi di kehidupan sehari-hari (Salafudin, 2015).

Menurut NCTM (2000) menyatakan bahwa pembelajaran matematika di sekolah dari jenjang sekolah dasar hingga sekolah menengah atas memerlukan standar pembelajaran yang berfungsi untuk mencetak siswa yang memiliki kemampuan berfikir, kemampuan penalaran matematis, memiliki pengetahuan serta kemampuan dasar yang bermanfaat. Standar pembelajaran meliputi standar isi dan standar proses. Standar isi merupakan standar pembelajaran yang harus dimuat konsep-konsep materi yang akan diberikan ke siswa, yaitu bilangan dan operasinya, aljabar, geometri pengukuran, analisis data danpeluang (Rachmayani, 2014).

Pembelajaran matematika memiliki standar isi yang dikeluarkan dalam Badan Standar Nasional Pendidikan (BSNP) mengemukakan bahwa penguasaan matematika tidak hanya penguasaaan fakta dan prosedur matematika serta pemahaman konsep, tetapi juga berapa kemampuan proses matematika siswa seperti pemecahan masalah, penalaran, komunikasi dan koneksi matematika (Lidinillah, 2018).Semua itu merupakan komponen yang saling mendukung dalam proses belajar matematika sehingga dapat membantu siswa dalam menguasai matematika yang dapat mempengaruhi hasil belajarsiswa (Hasratudin, 2013).

Hasil belajar matematika yang dipengaruhi aspek psikologi siswa seperti sikap, intelegensi, bakat, minat, motivasi dan kepribadian. Faktor psikologi ini merupakan faktor yang kuat dalam mempengaruhi hasil belajar siswa. Hasil belajar dapat ditunjukan dengan adanya perubahan pada siswa baik perubahan perilaku, pemikiran, kepribadian, dan intelegensisiswa (Lestariningsih \& Sholichah,2018). Menurut National Council of The Teachers Matematics (NCTM) (2000) standar matematika merupakan standar isi (mathematical content) dan standar isi (mathematical prosses). 
Menurut Amalia (2018) Pembelajaranmatematika memuat proses belajar yang dapat dirumuskan menjadi empat teorema menurut Bruner dan Kenney yakni: Teorema pengontruksian (contruction theorem) yang memandang pentingnya peran representatasi terkait konsep, prinsip, dan aturan matematika. Teorema penotasian (notation theorem) yang mana representasi akan menjadi lebih sederhana manakala dengan menggunakan simbol. Teorema pengontrasan dan keragaman (theorem of contrast and variation) yang memandang perlunya situasi yang kontras dan yang beragam. Dan Teorema koneksi (theorem of connectivity) merupakan teorema yang melihat matematika sebagai ilmu yang koheren dan tidak terpartisi atas beberapa cabang.

Kemampuan koneksi matematika merupakan standar proses dalam mempelajari matematika namun kemampuan siswa melakukan koneksi matematis masih rendah (Arsih, 2017). Tidak semua siswa yang memiliki kemampuan matematika yang baik dapat dengan mudah mengoneksikan matematika. Dalam hasil observasi di sekolah peneliti menemukan masalah yakni banyaknya siswa yang melakukan kesalahan dalam mengerjakan soal dan setelah dilakukan pengecekan siswa melakukan kesalahan dalam penggunaan konsep serta siswa kurang dapat mengoneksikan setiap konsep yang ada dalam matematika sehingga siswa mengalamami kesulitan dalam mengerjakan soal, hal ini berdampak pada hasil belajar siswa.

Penelitian ini menganalisis pengaruh kemampuan koneksi matematika terhadap hasil belajar siswa yang dalam hal ini akan menjelaskan ada atau tidaknya pengaruh dan pengaruh tersebut termasuk kedalam pengaruh positif atau negatif. Sehingga penelitian ini diharapkan dapat membantu dalam pengembangan kemampuan matematik siswa melalui kemampuan koneksi matematis siswanya. Penelitian ini mengambil dua kesimpulan yang akan dibuktikan yakni adanya pengaruh koneksi matematika terhadapa hsil belajar siswa kelas VIII SMP Negeri 2 Sumbergempol dan seberapa besar pengaruh kedua variabel tersebut. Penarikan kesimpulan akan menggunakan pendekatan kualitatif.

Sebelumnya juga pernah diadakan penelitian tentang kemampuan koneksi matematika oleh Nurfitria, Hudiono, \& Nursangaji (2013) yaitu "Kemampuan Dasar Matematika Siswa SMP" dalam penelitian terdahulu ini menggunakan pendekatan kualitatif dengan menggunakan tiga aspek kemampuan koneksi matematika yakni koneksi matematika dengan pokok bahasan lain dalam matematika, koneksi matematika dengan bidang ilmu lain dan koneksi matematika di kehidupan sehari-hari. 


\section{METODE PENELITIAN}

Penelitian ini menggunakan metode kuantitatif dengan menggunakan metode korelasi untuk menguji hipotesis penelitian yaitu adanya pengaruh kemampuan koneksi matematika siswa terhadap hasil belajarnya dan seberapa besar pengaruh kemampuan koneksi matematis terhadap hasil belajar siswa. Instrumen yang digunakan pada penelitian ini yaitu kisi-kisi soal, kartu soal, dan rubrik penilaian. Hasil belajar yang digunakan pada penelitian ini adalah hasil belajar ranah kognitif. Data yang telah didapat akan diolah dengan menghubungkan nilai atau angka yang dapat dihitung secara sistematis menggunakan perhitungan statistika. Metode ini disebut dengan metode kuantitatif karena data penelitian berupa angka-angka dan proses analisisnya menggunakan statistika (Sugiyono, 2017).

Penelitian ini dalam memahami permasalahan memerlukan desain atau rancanagan penelitian. Desain penelitian yang digunakan adalah One Shot Model yaitu model pendekatan satu kali pengumpulan data pada suatusaat (Arikunto, 2010). Penelitian ini juga menggunakan desain penelitian surveidikarenakan dalam penelitian ini tidak adanya tritment yang akan diberikan sebelum pengambilan data yang akan diteliti.

Pendekatan dalam penelitian ini adalah deduktif-induktif berangkat dari suatu karangka teori, gagasan para ahli, maupun pemahaman peneliti berdasarkan pengalamanya, kemudian dikembangkan menjadi permasalahan-permasalahan beserta pemecahanya yang diajukan untuk memperoleh pembenaran (verifikasi) atau menilaikan dalam bentuk dukungan data empiris dilapangan (Tim Laboratorium Jurusan, 2012). Indikator kemampuan koneksi matematis yang digunakan yaitu: (a) Mengenali dan memanfaatkan hubungan-hubungan antara gagasan dalam matematika; (b) Memahami bagaimana gagasan-gagasan dalam matematika saling berhubungan dan mendasari satu sama lain untuk menghasilkan suatu keutuhan koheren; (c) Mengenali dan menerapkan matematika dalam kontek-konteks di luar matematika (NCTM, 2000).

Teknik analisis data menggunakan uji statistik yakni uji t-test yang akan menguji adanya pengaruh kemampuan koneksi matematika siswa terhadap hasil belajar. Sebelum digunakannya uji T-test terlebih dahulu menguji homogenitas dan uji normalitas yang merupakan prasyarat penggunaan uji statistik parametrik. 


\section{HASIL DAN PEMBAHASAN}

Keadaan subjek penelitian sebelum tes yaitu masih memiliki kemampuan koneksi matematika yang rendah. Sebelum analisis data terlebih dahulu menguji apakah instrumen yang digunakan untuk mengambil data sudah valid dan reliabel apa tidak dan untuk menguji keabsahan instrumen penelitian. Uji validitas digunakan untuk menunjukanskor tes sejauh mana dapat memprediksi kriteria yang telah ditentukan. Sedangkan uji reliabilitas digunakan untuk mengetahui instrumen tersebut sama jika sekiranya pengukuran tersebut dilakukan pada orang yang sama pada waktu yang berlainan atau pada orang-orang yang berlainan (tetapi mempunyai kondisi yang sama) pada waktu yang sama atau pada waktu yang berlainan (Sugiyono, 2017).

\begin{tabular}{|c|c|c|c|c|c|}
\hline \multicolumn{6}{|c|}{ Correlations } \\
\hline & & item 1 & item 2 & item 3 & total \\
\hline \multirow[t]{3}{*}{ item 1} & Pearson Correlation & 1 & $.510^{\circ}$ & .122 & $.644^{\prime \prime}$ \\
\hline & Sig. (2-tailed) & & .031 & .631 & .004 \\
\hline & $N$ & 18 & 18 & 18 & 18 \\
\hline \multirow[t]{3}{*}{ item 2} & Pearson Correlation & $.510^{\circ}$ & 1 & .297 & $.862^{\prime \prime}$ \\
\hline & Sig. (2-tailed) & .031 & & .232 & .000 \\
\hline & N & 18 & 18 & 18 & 18 \\
\hline \multirow[t]{3}{*}{ item 3} & Pearson Correlation & .122 & .297 & 1 & $.675^{\prime \prime}$ \\
\hline & Sig. (2-tailed) & .631 & .232 & & .002 \\
\hline & N & 18 & 18 & 18 & 18 \\
\hline \multirow[t]{3}{*}{ total } & Pearson Correlation & $.644^{\prime \prime}$ & $.862^{\prime \prime}$ & $.675^{\prime \prime}$ & 1 \\
\hline & Sig. (2-tailed) & .004 & .000 & .002 & \\
\hline & $\mathrm{N}$ & 18 & 18 & 18 & 18 \\
\hline
\end{tabular}

\section{Gambar 1.Hasil SPSS Uji Validitas}

Uji validitas ini menggunakan microsoft excel dengan rumus Pearson yakni rumus yang ada dalam excel untuk menguji validitas suatu instrumen dan dengan menggunakan SPSS hasilnya sama. Penarikan kesimpulan validitas instrumen menggunakan $r$ tabel $<r$ hitung $=$ valid atau $\mathrm{r}$ tabel $>\mathrm{r}$ hitung $=$ valid dengan tingkat kesalahan $5 \%$ sehingga diperoleh ( $\mathrm{r}$ tabel 0,468 dengan $\mathrm{n}=18$ ). Sehingga dapat ditarik kesimpulan bahwa semua instrumen yang akan digunakan untuk mengambil data adalah valid. Uji reliabilitas ini menggunakan teknik Alpha yakni teknik uji reliabilitas pengujian soal yang berupa dikotomus atau esai. Uji ini menggunakan tingkat kesalahan 5\% dengan interpretasi: Alpha $>$ r tabel $=$ reliable, Alpha $<\mathrm{r}$ tabel $=$ tidak reliable Rumus Alpha (Riduwan, 2014). 
Instrumen penelitian didapatkan $0,547>0,468$ yang memenuhi Alpha $>\mathrm{r}$ tabel yang berarti instrumen penelitian ini reliabel. Sehingga Instrumen penelitian yang akan digunakan ini sudah memenuhi kreteria untuk digunakan dalam pengambilan data dilapangan yakni valid dan reliabel. Setelah data dinyatakan valid dan reliabel akan dilanjutkan analisis data berdasarkan informasi yang telah didapat.

Analisis data digunakan untuk menguji hipotesis penelitian dengan menggunakan statistika parametrik. Penggunaan statistika parametrik mensyaratkan bahwa data setiap variabel data yang akan dianalisis harus berdistribusi normal dan berasal dari populasi yang homogen (Riduwan, 2014). Analisis data ini semuanya menggunakan $\alpha=5 \%$. Terlebih dahulu analisis ini akan menguji homogenitas dan normalitas terlebih dahulu, namun uji homogenitas tidak diperlukan dalam penelitian ini dikarenakan sampel yang digunakan hanya satu kelas sehingga berasal dari orang yang sama dan dapat dipastikan data tersebut bersifat homogen.

Uji Normalitas, pengujian relliabilitas data dilakukan dengan uji KolmogorovSmirnov dan perhitungan dilakukan dengan bantuan aplikasi SPSS v-16,0. menggunakan uji Kolmogorov-Smirnov diperoleh nilai Kolmogorov-Smirnov adalah 0,588 dan nilai signifikansi 0,888 sehingga dapat ditarik suatu kesimpulan bahwa data ini berdistribusi normal dengan $\alpha=5 \%$ dengan $r$ tabel $=0,468$. Oleh karena itu penggunaan statistik parametrik untuk pengujian hipotesis dapat dilanjutkan.

\begin{tabular}{|ll|r|r|}
\hline \multicolumn{3}{|c|}{ One-Sample Kolmogorov-Smirnov Test } \\
\hline & & $\begin{array}{c}\text { kemampuan } \\
\text { koneksi } \\
\text { matematika }\end{array}$ & hasil belajar \\
\hline$N$ & 18 & 18 \\
Normal Parameters & Mean & 63.1111 & 63.2222 \\
& Std. Deviation & 13.81342 & 13.54537 \\
Most Extreme Differences & Absolute & .139 & .170 \\
& Positive & .110 & .170 \\
Kolmogorov-Smirnov $Z$ & Negative & -.139 & -.163 \\
Asymp. Sig. (2-tailed) & & .588 & .721 \\
a. Test distribution is Normal. & .880 & .676 \\
\hline
\end{tabular}

Gambar 2. Hasil SPSS Uji Normalitas

Pengambilan keputusan atau kesimpulan dilakukan berdasarkan pedoman dasar penarikan kesimpulan dan interpretasi yakni: Alpha $>\mathrm{r}$ tabel $=$ reliable, Alpha $<\mathrm{r}$ tabel $=$ tidak reliable. Hasil perhitungan SPSS ini dapat ditarik suatu kesimpulan bahwa dari $0,547>0,468$, yang menyatakan bahwa kesimpulannya data tersebut reliabel sehingga 
dapat digunakan dalam pengambilan data. Serta tingkat reliabilitasnya dalam katagori cukup, sehingga pengujian statistik dapat dilanjutkan yakni untuk menganalisis pengaruh kedua variabel penelitian.

Uji Korelasi Pearson Product Moment, kemudian akan dilakukan pengujian pada hipotesis pertama menggunakan uji koorelasi pearson product moment dengan bantuan aplikasi SPSS juga. Sebelum melakukan uji korelasi terlebih dahulu harus diketahui pedoman penarikan kesimpulan dan juga pedoman interpretasi koefisiennya yakni: Jika nilai signifikansi $<0,05$. Maka terdapat korelasi dan jika nilai signifikansi $>0,05$. Maka tidak terdapat korelasi

Tabel 1. Pedoman Untuk Memberikan Interpretasi Koefisien Korelasi

\begin{tabular}{cc}
\hline Interval Koefisien & Tingkat Hubungan \\
\hline $\mathbf{0 , 0 0 - 0 , 1 9 9}$ & Sangat Rendah \\
$\mathbf{0 , 2 0 - 0 , 3 9 9}$ & Rendah \\
$\mathbf{0 , 4 0 - 0 , 5 9 9}$ & Sedang \\
$\mathbf{0 , 6 0 - 0 , 7 9 9}$ & Kuat \\
$\mathbf{0 , 8 0 - 1 , 0 0 0}$ & Sangat Kuat \\
\hline
\end{tabular}

Hasil uji korelasi menunjukan nilai signifikansi korelasi $=0,01$ sehingga menghasilakan $0,01<0,05$ yang menyatakan adanya korelasi yang artinya terdapat pengaruh antara kemampuan koneksi matematis dengan hasil belajar siswa yakni yang diambil berdasarkan pedoman dasar pengambilan keputusan. Perhitungan ini menjawab rumusan masalah pertama, yakni $\mathrm{H}_{0}$ ditolak.

\begin{tabular}{|c|c|c|c|}
\hline \multicolumn{4}{|c|}{ Correlations } \\
\hline & & $\begin{array}{l}\text { kemampuan } \\
\text { koneksi } \\
\text { matematika }\end{array}$ & hasil belajar \\
\hline \multirow{3}{*}{$\begin{array}{l}\text { kemampuan koneksi } \\
\text { matematika }\end{array}$} & Pearson Correlation & 1 & $.706^{\prime \prime}$ \\
\hline & Sig. (2-tailed) & & .001 \\
\hline & $N$ & 18 & 18 \\
\hline \multirow[t]{3}{*}{ hasil belajar } & Pearson Correlation & $.706^{\prime \prime}$ & 1 \\
\hline & Sig. (2-tailed) & .001 & \\
\hline & $N$ & 18 & 18 \\
\hline
\end{tabular}

Gambar 3. Hasil SPSS Uji Korelasi Pearson Product Moment 
Pengujian seberapa besar pengaruh kemampuan koneksi matematika dan hasil belajar siswa atau rumusan masalah kedua. Dalam perhitungan diatas di peroleh $\mathrm{r}$ hitung atau nilai Pearson corelation $=0,706$ dalam SPSS yang termasuk dalam kategori kuat, kesimpulan ini berdasarkan dengan pedoman interpretasi koefisienkorelasi (Riduwan, 2014). Berdasarkan hasil analisis data didapatkan bahwa kemampuan koneksi matematika memilki pengaruh terhadap hasil belajar siswa yang pengaruh ini termasuk kedalam kategori kuat dan bernilai positif sehingga siswa yang memiki kemampuan koneksi matematis tinggi juga akan memiliki hasil belajar yang tinggi pula. Kemampuan koneksi matematis siswa memiliki fungsi untuk menghilangkan pembeda antar tiap materi dalam matematika maupun dalam bidang ilmu lain. Sehingga kemampuan koneksi matematika siswa yang tinggi dapat memudahkan siswa dalam memahami materi serta pengetahuan yang telah diperoleh akan lebih bertahan lama dikarenakan siswa dapat mengaitkan antara materi satu dengan materi yang lain (Puteri \&Riwayati, 2017).

\section{KESIMPULAN}

Kemampuan koneksi matematis terhadap hasil belajar siswa memiliki pengaruh dan pengaruh tersebut tergolong dalam kategori kuat dengan hubungan yang positif. Hal ini dapat diartikan bahwa siswa yang memiliki kemampuan koneksi matematis tinggi secara otomatis juga akan memilki hasil belajar yang tinggi pula, sebaliknya jika siswa memiliki tingkat kemampuan koneksi matematika rendah maka akan berpengaruh terhadap hasil belajar yang ikut rendah. Kemampuan koneksi matematika siswa yang telah terbukti dapat mempengaruhi hasil belajarnya akan memudahkan siswa dalam mengaplikasikan materi matematika kedalam kehidupan sehari-hari dan juga siswa dapat mengaitkannya dengan bidang ilmu lain. Siswa akan lebih mudah memahami bidang ilmu lain yang memilki kaitan dengan matematika.Berdasarkan simpulan di atas, maka disarankan kepada guru agar dapat mengembangkan kemampuan siswanya dalam hal kemampuan koneksi matematis mereka yang dalam hal ini akan memiliki pengaruh positif untuk hasil belajar siswa. Sehingga siswa bisa memahami pelajaran lebih baik dan lebih terstruktur lagi. 


\section{DAFTAR PUSTAKA}

Amalia, L. (2018). Pengembangan Soal Untuk Mengukur Kemampuan Koneksi Antar Topik Matematika Siswa Sekolah Dasar. Jurnal Pendidikan Matematika RAFA, 3 (2), 195-206.

Arikunto, S. (2010). Prosedur Penelitian Suatu Pendekatan Praktik. Jakarta : PT Rineka Cipta.

Arsih, U.D. (2017). Pengaruh Kemampuan Koneksi Matematis Siswa Dengan Media Bangun Ruang Pada Materi Luas Permukaan Bangun Ruang Kelas VIII Di SMP N 1 Prambon. Jurnal Simki-Techsain, 1 (5), 1-4.

Hasratudin.(2013). Membangun Karakter Melalui Pembelajaran Matematika. JurnalParadikma, 6(2), 130-141.

Lestariningsih, L., \& Sholichah, B. (2018). Pengaruh Sikap Siswa Pada Matematika Terhadap Hasil Belajar Materi Persamaan Kuadrat. Jurnal Pendidikan Matematika $R A F A, 3(2), 207-213$.

Lidinillah, D.A.M. (2018). Investigasi Matematika dalam Pembelajaran Matematika di Sekolah Dasar". Dalam http://file.upi.edu, di akses pada 23 Maret 2018.

NCTM. (2000). Principles and Standards for School Mathematics. United States of America : The National Council of Teachers of Mathematics, Inc.

Nurfitria, Hudiono, B., \& Nursangaji, A. (2013). Kemampuan Koneksi Matematis Siswa Ditinjau Dari Kemampuan Dasar Matematika Di SMP. Jurnal Pendidikan dan Pembelajaran, 2(12), 1-17.

Puteri, J.W., \& Riwayati, S. (2017). Kemampuan Koneksi Matematis Siswa Pada Model Pembelajaran Conneted Mathematics Project (CMP). Jurnal Fibonacci (Jurnal Pendidikan Matematika dan Matematika), 3 (2), 161-168.

Rachmayani, D. (2014). Penerapan Pembelajaran Reciprocal Teaching Untuk Meningkatkan Kemampuan Komunikasi Matematis Dan Kemandirian Belajar Matematika Siswa.Jurnal Pendidikan UNSIKA, 2 (1), 13-23.

Riduwan.(2014). Dasar-Dasar Statistika. Bandung : Alfabeta

Salafudin. (2015). Pembelajaran Matematika yang Bermuatan Nilai Islam. Jurnal Penelitian, 12 (2), 223-243.

Sugiyono. 2017. Metode Penelitian Pendidikan Pendekatan Kuantitatif, Kualitatif dan $R \& D$, Bandung : Alfabeta.

Tim Laboratorium Jurusan. (2012). Pedoman penyusunan skripsi STAIN Tulungagung. Tulungagung: STAIN Tulungagung. 